\title{
An Important \\ Source of Information about Islamized Armenians
}

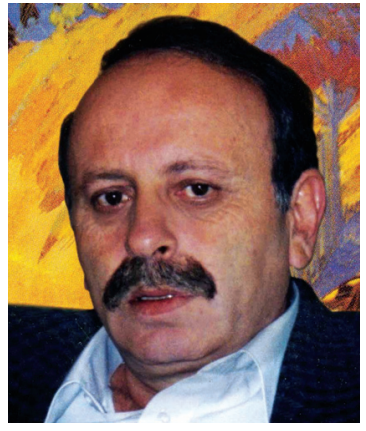

Sergey Vardanyan

Gor centuries the history of the Armenians has been

- accompanied by struggles against foreign yoke, massacre, attempts of forced Islamization. The Islamized Hamshen-Armenians (Hamshenis) are of particular interest. As far back as in the $19^{\text {th }}$ century several Armenian and foreign scholars such as Ghukas Inchichean (1806:396-397), Minas Bzhshkean (1819:92-93,97), German scholar Karl Koch (1846), Sargis Haikuni (1895:239-243; 1903:702-709), P. Toumayeants (1899:174-177) and others mentioned these Armenians. The listing, however, should start with a member of the Mekhitarist Congregation - Poghos Meherean. The latter was in the village of Khevak of Hamshen (also known as Hamshin, Hemshin) as far back as in 1776 and provides us with highly important information in his reminiscences "The Life Story ...."1.

Poghos Meherean was born in 1729 in the village of Arinch in Mush and became a clergyman in 1767 (Mkhitarean yobelean... 1901:218). He obtained valuable manuscripts for the matenadaran (depository of ancient manuscripts) of the Mekhitarist Congregation (Sargissean, Sargsean 1966:1-49; Tchemtchemean 1993:19)2 . He visited a number of countries in Europe (Hungary, Germany, Holland, Italy, etc.) and in the East (Turkey, Egypt, Syria, etc.). He even reached India and in 1811 wrote about all these visits with a lively style in his reminiscences which are of exceptional value. $P$. Meherean died in 1814, February 26 on the Island of St. Lazarus, Venice at the age of 85. (Mkhitarean yobelean 1901:218) Though Ghukas Inchichean published the first volume of his "The Geography of the Four Parts of the World" in 1806, i.e. before Meherean wrote his memoirs, while comparing his articles about the village of Khevak, Hamshen with those given by Inchichean, one may assume that the source of information (maybe oral) is Poghos Meherean. In one of the chapters of his book called "Hemshyre or Hamshen" Ghukas Inchichean writes: "Khevak is a village at an 8-hour walk from Hamshen and a three-hour walk from Khotorjur in the southern part, built on a slope of a high mountain; the population is mostly made up of Turks, 200 families of which used to be Armenians; 5 or 6 families still remained Armenians; the village is known for its high-quality honey; the Pejanket tributary crosses Khevak and flows into the Tchorokh)". (Inchichean 1806:397)

In 1843-1844, i.e. 70 years after Poghos Meherean, Karl Koch, a professor of the University of Berlin and Yena, and a famous scholar, was in Bardzr Hayq and the 
Tchorokh Basin. According to him, Khevak which was included in the province of Berdagrak, "is made up of 5 districts (or parts) and has 200 houses with a population ranging from 1000 to 1200". (Tashean 1980:218) Koch also mentions Greek and Armenian Christians along with the Muslims who formed the majority of the population in Khevak: "Today only 2 villages (Karmirk and Khotorjur) are the only habitats of Armenian Christians while in the 4 other villages (Kutrashen, Nikhagh, Mokhrkut and Khevak) Greek and Armenian Christians live side by side with Muslims". (Ibid.:281)

Hakobos Tashean, who was quite familiar with Bardzr Hayq and the Tchorokh Basin writes: “... there were already Armenians with Georgian ritual traditions in Berdagrak and in Tortum. Armenians belonging to the Georgian church, native Georgians and Christian Lazes could also be found among them. Most probably the descendants of these Lazes came to live side by side with the so-called "Greeks" who were mentioned here and there at the beginning of the early $19^{\text {th }}$ century. They, being of a smaller number than the native Greeks, have disappeared. Nevertheless, it is possible that families of native Greeks could have also settled here and could have been registered on this or that occasion". (Ibid.: 214-215)

Meherean also mentions a Georgian monk who was a pastor "in the villages near Khevak that professed the religion of Greeks". (Meherean, Manuscript 560:168-169)

There are also similarities between Meherean's and Koch's extended descriptions of the severe climate in the nearby mountains. Meherean was in Khevak in September and writes that "no one could pass" those mountains already covered with thick snow in October. Koch visited the same places in August and very expressively portrays the freezing panorama not typical of a summer: "An icy wind was blowing bitterly when, at last, for the second time we reached the peak of the Pontic Mountain Chain. The mount in Khevak which we passed yesterday, lay below. Only a dark-brown pile of rocks made up of ruins and enormous massive peaks covered with eternal ice and snow that resembled the peaks of Helueti, rose above us. About 100 feet above a water circle could be seen that had turned into ice in the course of many centuries and no sun ray could bring it back to its former state. Though my body shivered with cold from time to time, I managed to climb up another height and suddenly the sparse flora vanished. On my left I could see Kajkar, the peak of which I was unable to see because it was too close to me. A lower mountain was leaning on this immense mountain rising between the Black Sea and the Tchorokh River. Only several peaks pierced into the clouds. So, I was not lucky enough to see the sea which could be reached 8 hours later if we took the straight road". (Koch 1846:100-101; Tashean 1880:89-90; Houlunean, Hatchean 1964: 96-98)

Ghevond Alishan also writes about the village of Khevak in his "Teghagir Hayots Metsats" (Topography of Great Armenians). Noting, mistakenly, that Hamshen belonged to the "state of Erzrum" (Alishan 1855:36-39), he writes that Hamshen is rich in honey and that "in the middle of the previous century its Armenian population was converted into Muslims, but they still preserve their Armenian names and traditions. Among the most famous villages of Hamshen is Khevak, a spot of Khachekars". (Ibid.:39) Though Alishan made no references to his work called "Sisuan" we infer that he had already read Meherean's manuscript. While speaking about Peylan Alishan writes: "One of our 
Fathers [Mekhitarists] stayed here in 1773". And then he presents an extract from Mehrean's reminiscences and mentions in the footnote "Poghos Meherean of the village of Arinch in Mush" without any reference as to when Meherean lived and what handwritten or printed source he had taken that large passage from. This, probably, is the first indication of P. Meherean's name in printed sources. (Alishan 1885:420, 421)

In 1907, a century after Gh. Inchichean, S. Eprikean, another Mekhitarist member, in the second volume of his "Patkerazard..." (Dictionary of Illustrated Homeland) making abundant use of Gh. Inchichean's and partly Alishan's works, writes about 'Khevak - a village in Hamshen about 3-hours' walk from Khotorjur and 8-hours' walk from Hamshen, built on the slope of a high mountain. In the mid $18^{\text {th }}$ century 200 Armenian families were Islamized. There is also a small number of Catholic Armenians. The honey of the village is perfect". (Epikean 1907:167) ${ }^{3}$ It is not difficult to see that the only novelty is the indication of Catholic Armenians in Khevak. Barsegh Sargissean was the first to attach special importance to the handwritten reminiscences of Poghos Meherean. In his "Usumnasirutiwn..." (A Study of Messalian-Pavlikian Tondrakiys' Sect and the Letter of G. Narekatsy), retelling about the sectarian Armenians Meherean had met on his way from Aleppo to Karin in 1773 (the Tonraketsi ${ }^{4}$, the Keskes ${ }^{5}$ or the Arevordi6") and the stories of false Bishop Hovhannes from Burchimasur, he writes that Meherean "recalled the 200 Islamized Armenian families in Khevak" and adds in the footnote: "This unpublished work, that is now in our matenadaran is a very relevant material about the contemporary history and state of the Armenian people of the given period". (Sargissean 1893:102-104)

B. Sargissean refers to Meherean's reminiscences later, too. In his article "Vichakagrakan nor..." (A New Statistical Theory for the Benefit of Independent Armenia) published in "Bazmavep" he tells the story of Meherean's meeting with the Islamized people in the village of Khevak.

"And Poghos Vardapet Meherean who 30 years after Inchichean, i.e. in 1776, travelled to Hamshen, describes in vivid colours the unusual reception by his own kins who had been converted to Turks in the village of Khevak and in the surrounding villages and presents a really pathetic scene. Hearing that he was a clergyman, people crowded around, kneeled and kissed his hand and stared at his companion standing on the table that served as a church stage. Thus, he guessed that they had ceased being Christian Armenians but they had not forgotten it. He looked for the church and found it, which, like a reasonable widow who had been left alone by its apostate sons, was still pure and blameless though closed. He made them open the church, cleaned it and after celebrating the Holiday of St. Cross with the help of the four newly-ordained clergymen accompanying him, he also officiated a liturgy .

The voice of the mysterious song aroused the remorse of the apostates. They began to recollect the faith of their grandparents and mothers and tried to rush in. He tried to block their way but in vain. He commented on "The Testament" to the people from the neighboring villages in Arabic reminding them about the faith of the ancestors of theirs. And being extremely excited he left the village, for in those days of persecution he could be arrested as a prang [ed.Catholic]" (Sargissean 1919:284-285) ${ }^{7}$. 
Drawing a comparison between the version told by B. Sargissean and the original by P. Meherean, it is not difficult to notice that he presents the aforementioned passage with a style and comparisons typical of fiction. Sometimes he gets off the point and makes unnecessary complements writing that Poghos commented on the Testament in Arabic (Nor bargirq haykazean lezoui 1837:2; Zhamanakakits hayots lezvi batsatrakan bararan 1974:250). This can give rise to groundless conclusions about the people of Khevak and those of the surrounding villages being speakers of Arabic. He writes that Poghos left Khevak hastily as he was afraid to be arrested as a "prang" while this haste can be explained not only by his fear of being accused as a Catholic but by the truly dangerous reality. As it is known, the reconversion of Muslims to Christians, i.e. "making them Armenians again" by a clergyman was a capital crime in the Ottoman Turkey.

In his book "Hay bnakchutyuny Sev tsoven..." (The Armenian Population from the Black Sea to Karin) (Tashean 1921:81) and in the first and, particularly, the second volumes of his three-volume "Tayq, Neighbors and Khotorjour" Hakobos Tashean mentions Khevak several times. (1973-1981) Unfortunately, he is unaware of Meherean's reminiscences, though, as we have already stated, B. Sargissean mentions the name of Meherean and the village of Khevak found in Meherean's reminiscences, in his abovementiond book and in his article entitled "A New Statistical Theory...". Thus, Hakobos Tashean would have been able to answer a number of questions with Meherean's assistance. In one of the chapters of his research entitled "The Islamization of Khevak" H. Tashean writes: "Unfortunately, we do not have detailed information, about the Islamization of this province. At least it is not known to us. The essential information is provided by Inchichean. Various information is given by Koch, too. But it is only this much" (Tashean 1921:216).

About two centuries after the conversion, we find relevant evidence about the people of Khevak being Armenian speakers in the works by H. Tashean. In 1910-1911 (Ibid.:6) travelling from the Black Sea to Karin, he writes:

"During our trip we questioned the people we met about this or that Armenian word that was used by them, asking for interpretation deliberately, as if we did not know the answer, and we saw that the Turkish equivalents of many of these were unknown to them. 'They call it this way in our village', this was the only explanation. More and more often we came across cases when the early Islamized (e.g. the people of Khevak) pretended as if they could not speak any other language except Turkish but they understood Armenian fully." (Tashean 1973-1981:150)

" Even today the people of Khevak, at least most of them, either know Armenian or understand it though they (particularly the men) speak Turkish to foreigners. The Islamized have preserved Armenian proper surnames (Keshish-oghlu; Makar-oghlu; Minas-oghlu, etc).” (Ibid.:219)

"These forcibly Islamized people still remember their kinships and in-law relations with the Christian relatives who had left the country and emigrated to other countries mainly to escape religious violence. The writer of these lines had a chance to get acquainted with the Islamized inhabitants of Khevak in Karin who used to come here to pay visits to their relatives and who knew Armenian.” (Tashean 1921:81) 
From the book by F. Hakob Qosean "Bardzr Hayq. Karin qaghaqy...” (1925) we learn that in 2 records out of 3 belonging to the people of Khevak in Karin, the village is mentioned as Khevek. E.g. in the "List of Liturgies" engraved in the marble of the left wall of the Armenian St. Astvatsatsin Church (built in 1842), one can read: "Master Sargis Grigorean from Khevek". Gravestones were found in the Armenian cemetery engraved "Zorapean Grigor from Khevak" (in 1871) and "Pnavetis Arakelean from Khevek" (in 1872) (Ibid.: 460, 464, 479, 480). Not all the gravestones bear the indication of the birthplace, so it is quite possible that there were other tombs belonging to the people of Khevak, as well.

"Haykakan sovetakan hanragitaran" (the Armenian Soviet Encyclopedia) refers to the village of Khevak, too. T. Gevorgyan, the author of the material on Khevak in the Encyclopedia, for unknown reasons, ascribes the Islamization of the Armenian families to the first half of the $19^{\text {th }}$ century while Meherean and other sources point at the first half of the $18^{\text {th }}$ century. "Khevak - an Armenian-speaking Muslim village in Western Armenia, situated in the Province of Kiskim, in Erzrum on the eastern slope of Kaj(k)ar Mountain to the north of Kiskim was mostly engaged in apiary (the village was famous for its high quality honey), cattle-breeding, farming. The Christian Armenians of Khevak (nearly 200 houses) were forced to convert to Islam in the mid 19th century. Some escaped and found shelter in Khotorjur and Karin. At the beginning of the $20^{\text {th }}$ century only ten Armenian houses adopted Muslim during the Armenian Genocide in 1915. The Armenian Church in Khevak that has now been turned into a mosque, is still preserved" (Haykakan sovetakan hanragitaran 1979:47). Unfortunately, being familiar with other sources, the authors of "Hayastani ev harakits shrjanneri teghanunneri bararan" (Dictionary of the Place Names in Armenia and Surrounding Areas) quote T. Gevorgyan, hence, repeating his mistake:

"Khevak, Kheva, Khevi - a village in Western Armenia, in the Province of Erzrum, in the small province of Kiskim, to the left of the Tchorokh River, near the mouth of its left tributary Kobaksu, on the eastern side of Kajkar (Khachekar) Mountain. The Bejanget River that passes through the village is also known as the Khevak. At the beginning of the $19^{\text {th }}$ century nearly 200 Armenian families and churches were engaged in apiary, cattle-breeding, farming: The majority of the Armenian population was forced to adopt Islam in the first half of the $19^{\text {th }}$ century. The rest left the village. In the early $20^{\text {th }}$ century only 10 Armenian families remained in the village". (Hayastani ev harakits shrjanneri teghanunneri bararan 1988:720)

If there were really 10 Armenian Christian families left in the early $20^{\text {th }}$ century, then it is not clear why A-Do, who, while travelling about the state of Erzrum in 1909 and collecting information about the Armenian population of Kiskim in his work "Vani, Bitlisi ev Erzroumi vilayetnery" (1912:5) singles out only 6 villages out of the 68 as having Armenian inhabitants. The 6 villages were: Khotorjur (with its seven villages or districts), Karmrak, Gasapa, Prtikner, Nikhakh, Kutrashen. Khevak is not mentioned, whereas Gasapa with only 15 houses and Nikhakh, made up of only 7 houses are indicated (199).

In the "Patkerazard..." (Illustrated Dictionary of Homeland) by S. Eprikean, 
published in 1907, listing the 278 villages of Karin that were inhabited by Armenians, Turks and were known to have a mixed population, the author does not mention Khevak. (Eprikean 1907:51,300-301)

Thus it follows that the sources as to where Khevak belongs to are diverse. P. Meherean, Gh. Inchichean, Gh. Alishan, S. Eprikean, B. Sargissean as well as B. Torlaqyan consider it to be one of the villages of Hamshen. K. Koch, T . Gevorgyan and the authors of "Hayastani ev harakits shrjanneri teghanunneri bararan" (Dictionary of the Place Names of Armenia and Surrounding Areas) place it in the small province Kiskim (Berdagrak) of Erzrum villayet. Tashean, placing Khevak in Kiskim, thinks it possible that the border of Hamshen once reached the southern slopes of the Pontic Mountain Chain including Khevak, too: "Thus, Inchichean places Khevak in Hamshen as a separate village. Due to its position it could be seen easily, though being separated from Hamshen by such a mountain chain covered with eternal snow, the impassability of which is so nicely described by Koch". "It can be seen, however, that Hamshen once used to stretch to the southern slope of the Pontic Mountain Chain." (Tashean 19731981:197) Further research is required to show how convincing H. Tashean's assumptions are. With the desire to put it in action in the scientific circles, we present to your attention extracts scattered on different pages of P. Meherean's reminiscences which are of exceptional importance for the study of the history of converted Armenians ${ }^{8}$. The publication also comprises evidence about the clergymen in Khotorjur in the $18^{\text {th }}$ century. It should be noted that the adoption of Catholicism started in the second half of the 17th century (Houlunean, Hatchean 1964:165) and already in 1748, according to a report sent to Vatican from Constantinople, in all the villages of Khotorjur there were Catholic Armenians with one or two vicars also Armenians by origin. (Hofmann 1935:128-129)

Extracts adduced below introduce Meherean's interpretation of the events.

“... They brought two psalm-readers from the village of Karmirg and another one from the village of Mokhrakuit and one named Serobe from the village of Khevak, Hamamashen Province. The people of Karmirg - the vicar and the inhabitants and those of Mokhrakuit approved of their readers. As to Serobe from Khevak, he had no one from his village to speak for him. Hence, the elderly vicars of Khotorjur told the following story, "When the people of Khevak were converted to Turks there remained only five or six Christian families for which the vicars of Khotorjur served as religious leaders. There lived an old man, the father of this psalm-reader Serobe. When he was down with illness he called his Christian brothers of Khevak and said to them, "My dear brothers, you know that 200 homes among our villagers have become Turks and only our sacred faith in God spared us. So, now we do not have a vicar and I fear that our and your sons will lose their true way without a vicar. Then they asked him, "Ter, what shall we do?". The old man said to them; "Look, my son Serobe is 9 years old. I will give you 2000 dahekans to send 
my son to Khotorjur, to their metsavor Ter Hakob. Let him stay there and learn and when time comes, bring him back and ordain him not to let our sons get lost, as it happened to our villagers". Ter Hovsep from Khotorjur, Ter Margar from Chichapagh, Ter Alexan and Karapet from the Village of Syuni, Ter Poghos from Kaghmkhut, Ter Hovhannes from Khantadzor and many others confirmed all this. (p. 161-162)

And as to these two psalm-readers from Karmirk, one from Mokhrakuit and Serobe from Khevak, they were ordained taking into consideration the wish of the people and the priests (p. 164) .

Several days after the celebration of Virgin Maria in Khotorjur, I took the newlyordained vicars - Ter Avetis from the village of Mokhrakuit, Ter Serobe from Khevak, Ter Petros from Chichapagh and left for Mokhrakuit where Ter Avetis served a grand liturgy. Then I took the officiating priest home in his liturgy clothes with cymbals and singing church psalms on our way, in accordance with the Armenian ritual.

... Several days later, I took Ter Petros, the newly-ordained Ter Avetis and Ter Serobe from Hamshen with me and set out for the village of Khevak in Hamamashen but it was bitterly cold and stormy on the way, and we all lost the slightest hope to survive. I made an attempt to make them eat but the meat was terribly frozen. Halve ${ }^{9}$ had especially hardened into stone and they were unable to eat it. Then, it was September and they said it was impossible for anyone to pass those places in October that's why people went to Khevak along the River Tchorokh. Coming down the mountain we went to Khevak and when we entered the village the men and women of the village who had become Turks gathered around me and were kissing my hand. Here we stayed in the house of the newlyordained Ter Serobe, who had uncles here who were quite well-off. First, we put a table and together with Ter Petros and Ter Avetis I served the liturgy and the people who had become Turks came to the house to see the liturgy. I asked them if there was a church there and they said, "Yes, but it is ruined". And when I saw that it was quite easy to repair it I did so at once, cleaned it with the help of five or six other people. Then I washed the hard stone with water and wine as the door had been closed and no one had come in or out, I sanctified it and we - the three vicars, served a liturgy. And the converted filled the church in the course of the mass and I could not drive them away with my crosier. I feared they might inform on me to other people saying that the preacher had come to turn the people of Khevak back into Armenians. And in the month of September we all gloriously celebrated the Holiday of the Great Cross. One Georgian priest, named Ter Israyel, who used to preach in one of the nearby villages in Khevak in the Greek tradition, following our ceremonial tradition, tried to bring them back to the right faith. Without giving thougth to it he intended to change his ritual bringing it close to ours, especially as far as the consecrated bread was concerned. I forbade him presenting many examples and 
persuading him against doing it. 'If you bring your villagers closer to the Church of Christ and change your Greek rituals, you will not be able to control your people'. After this, I promised him a gown for liturgy according to the Greek ritual. Then, as I had promised, I sent him all the necessary clothes together with their ornaments from Gimishhana.

And after the liturgy, according to my nation's traditions, we left the church with a chasuble and a cross and set out to bless the graves of the perished Christians. The converted gathered around us, put food on the tombs of their fathers and each of them begged and implored me to come and consecrate the graves of their ancestors as they had been Christians. Others felt guilty of being faithless and asked me, especially the elderly, to listen to their confessions. However, there were some women who had remained faithful to their religion and I taught them the basic elements necessary for the faith. I absolved their sins and assigned the newly-ordained Ter Serobe to take care of them. I left Ter Petros of Khotorjur in Khevak, and took Ter Serobe and went to their home town that was only an hour's way from Khevak. It lay between thick big trees and several farms where one could find sheep, cows, bees and a small hut belonging to Ter Serobe. Here we spent the night and in the following morning we performed a mass after which I was asked to bless the farm, the sheep and the oxen. Then we had dinner. Later they gave us food to take with us to eat it on our way. They put some snow-white and delicious honey, tasty butter, excellent cheese, etc. in our bags. From here we went down to the gorge - to the bank of the River Tchorokh.

And we were walking along the bank of the river, decorated with vineyards, gardens of olive-trees and with marvelous fruit-trees. I walked around but I could not see good fruit anywhere. The fruit was lying right on the road, squeezed under the feet of passers-by. The soil was drenched with the fruit pulp. There were very big pomegranatetrees, the branches of which were intertwined. I was moving under the trees on horseback. Big and blown-up pomegranates could be seen hanging on the trees or lying along the road. I picked them up and ate them with great pleasure. And to my question why they let such good fruit get spoilt they said. "What shall we do, then? There is no one to buy them". And when I offered them money for fruit they answered, "Go to the garden and take any fruit you wish, eat it, take it with you and please, pray to the God for the souls of those who have planted these trees and for the souls of our ancestors who were Christians". Though their ancestors had changed their religion they were quite gentle, polite and hospitable. They kissed my hand, took me to their place to read the Testament for their sick relatives as they really believed in the power of the Testament. It took us three days to go to Ardvin from Khevak. On October 5,1776, I stayed at Ter Hovsep's place who received us with pleasure. So did the citizens". (p. 167-170)

Notes:

1. See the detailes in: Patmutiwn Varouts Tearn H. Poghos Vardapeti Meherean // Sharagreal Yiwrme in 1811 in Venetik, i Vans Srboyn Ghazaru. The Matenadaran of the Mekhitarist Congregation of Venice, Manuscript 560. 
2. In 1775 F. Poghos assigned a psalm-reader and peddler to find manuscripts in provinces. In Hamshen the psalm-reader stayed in the house of an Armenian, forcibly Islamized 60 years before. Here, he was told that every Saturday evening, the host lit a candle in honour of the Testament (in reality it was a Mashtots). The psalm-reader was able to buy this most valuable book after many pleas. F. Poghos later sent it to Venice. The manuscript which dates back to the $9^{\text {th }}-10^{\text {th }}$ centuries is still believed to be the oldest Mashtots ever found. (Sargissean, B.; Sargsean, G. 1966 p.4-5; Tchemtchemean, S. Mayr Tsutsak... p. 19; H. Gr. A Mashtots // Bazmavep // 1949, N5-6, p 114-115).

3. In the explanation of the word Kheva that precedes that of Khevak, S. Epikean indicates "a village in the province of Artanouch, one family of Armenians and 23 Turkish ones. There are 2 other villages with this name in the province of Artahan". Barunak Torlaqyan, one of the best experts of the ethnography of the people of Hamshen, most probably got the data on Khevak from S. Eprikean. In one of the parts of his study entitled "The region of Hamshen" he writes: "Khevak - 8-hours' drive from Hamshen to Khotorjur, located on a high mountain, a village populated by Islamized Armenians. The village is noted for its high quality honey." (See B. Torlaqyan. Hay Azgagrutyun ev Banahyusutyun. // Nyuter ev usumnasirutyunner. N 13, Hamshenahayeri azgagrutyuny. Yerevan, 1981, N 13, p. 29) In his book the village of Khevak is marked in the territory of the province of Hamshen, on the slopes of the Parkhar mountain range. (The approximate schematic map of the settlements as of 1915 is known as "Hamshenahayer ev pontahayer") The source is not given.

The village of Khevak is named Khevi on Russian maps. According to the dictionary, there used to be a village called Kheva in the region of Artanouch of the district of Ardvin in Batumi and two others in the district of Ardahan in the region of Kars. (T. Hakobyan, S. Melik-Bakhshyan, H. Barseghyan. Hayastani ev Harakits Shrjanneri Teghanunneri Bararan. Yerevan, 1988. p. 720. Vol. 2)

4. Tondraketsi - a sectarian social movement in Armenia in the $9^{\text {th }}-11^{\text {th }}$ centuries. The movement was initially launched in the small town of Tondrak, hence the name of the movement.

5. Keskes - half-Christians and half-Muslims.

6. Arevordi - descendants of the Christian sectarian movement in the $11^{\text {th }}-12^{\text {th }}$ centuries in Cilicia and Armenia. Armenians and probably Assyrians by origin. Worshiped the Sun, the poplar and lilies.

7. In 1992 the historian S. Poghossyan came up with a more concise exposition of what Barsegh Vardapet Sargissean told. See S. Poghossyan. Sev Tsovits Vana Tsov, Hing Amis Hing Or. Yerevan, 1992, p. 22.

8. A small extract was published from "Hamshentsi Musulman Hayeri Usumnasirutyan Patmutyunits" by S. Vardanyan // Iran-Name. 1998, p.2, N 1-2-3; see also: S. Vartanian. Des Armeniens oublies // Azad magazine. Grenoble, 1999, p.16, N3. 
9. The word derives form an Arabic root and is used to describe many distinct types of sweet confection, across the Middle East, Central Asia, and South Asia. It is made from a variety of ingredients, including sunflower seeds various nuts, beans, lentils, and vegetables, such as carrots, pumpkins, yams, and squashes .

\section{References:}

1. A-Do. (1912) Vani, Bitlisi ev Erzroumi Vilayetnery. Yerevan.

2. Alishan, Gh. (1855) Teghagir Hayots Metsats. Venice: St. Lazarus.

3. Alishan, Gh. (1885) Sisuan. Venice: St. Lazarus.

4. Bzhshkean, M. (1819) Patmutiwn Pontosi, Vor e Seaw Tsov. Venice: St. Lazarus.

5. Conybeare, Fred. C. (1898) The Key of Truth, a manual of the Paulician church of Armenia. Oxford.

6. Eprikean, S. (1907) Patkerazard bnashkarhik bararan, Venice: St. Lazarus. Vol. 2.

7. Ghazaryan, A.; Levonyan R.N. (1999) Hayastanyayts avetaranakan yekeghetsi (Hayastan-Kovkas). Yerevan: Haykakan hanragitaran press.

8. Grigoryan, V. (1960) Nor teghekutyunner "Banali tchshmartutyan" yerki heghinak Hovhannes yeretsi masin. // Banber Matenadarani, N5.

9. Hakobyan, T; Melik-Bakhshyan, S.; Barseghyan, H. (1988) Hayastani ev Harakits Shrjanneri Teghanunneri Bararan, Yerevan: Yerevani hamals. hrat. Vol. 2.

10. (1979) Haykakan sovetakan hanragitaran. Yerevan: Yerevani hamals. hrat. Vol. 5.

11. Haykuni, S. (1895) Nshkharner. Korats u moratsuats hayer (Trapizoni haymahmetakan giwghern u nrants avandutiwnnery) // Ararat. Vagharshapat: Sourb Ator. N7, N8.

12. Haykuni, S. (1903) Ter Karapet qahanay Toroslitsi // Manandean Y.; Atcharean H. Hayots nor vkanery (1155-1843). Vagharshapat: Sourb Ator.

13. Haykuni, S. (1905) Yuseptsi Azgatohm ew tarorinak awazak Abrieom Trapizoni aay aiwgheru mej (1795-1840). Vagharshapat: Sourb Ator.

14. Houlunean, Y.; Hatchean M. (1964) Hushamatean Khotorjuri. Vienna: Mekhitarist Press.

15. Inchichean, Gh. (1806) Ashkharhagrutiwn Chorits Masants Ashkharhi. Venice: St. Lazarus. Vol. 1.

16. Karnetsi, Ghukas (2003) Divan hayots patmutyan. Book 1. Yerevan: NAS, Gitutyun. Vol. 2.

17. Koch, K. (1846) Wanderungen im Oriente während der Jahre 1843 und 1844, II, Reise im pontischen Gebirge und türkischen Armenien. Waimar. Landes Industrie Comptoirs.

18. Meherean, P. Patmutiwn Varouts Tearn H. Poghos Vardapeti Meherean, Sharagreal Yiwrme 1811 Venetik, $i$ Vans Srboyn Ghazaru. // The Matenadaran of the Mekhitarist Congregation of Venice, Manuscript 560.

19. (1901) Mkhitarean Yobelean 1701-1901. Venice: St. Lazarus.

20. (1837) Nor Bargirq Haykazean Lezoui. Venice: St. Lazarus. Vol. 2. 
21. Qosean, H. (1925) Bardzr Hayq. Karin Qaghaqy (Teghagrutiwn, Patmutiwn ew Sovorutiwnner.) Vienna, Mekhitarist Press. Vol. 1.

22. Sargissean, B. (1893) Usumnasirutiwn Maniqea-Pawghikean Tonraketsineru Aghandin ew Gr. Narekatsvoy Tughty. Venice: St. Lazarus.

23. Sargissean, B. Sargsean, G. (1996) Mayr tsutsak hayeren dzeragrats matenadaranin Mkhitareants i Venetik. Venice. Vol. 3.

24. Sargissean, B. (1919) Vitchakagrakan nor tesutiwn my i npast ankakh Hayastani. // Bazmavep, Venice: St. Lazarus. N9.

25. Tashean, H.Y. (1980) Tayq, Dratsiq ew Khotorjour (Patmakan-teghagrakan Usumnasirutiwn). Vienna: Mekhitarist Press. Vol. 2.

26. Tashean, Y. (1921) Hay bnakchutiwny Sev tsoven minchew Karin (Patmakanazgagrakan harewantsi aknark my). Vienna: Mekhitarist Press.

27. Tchemtchemean, S. (1993) Mayr tsutsak hayeren dzeragrats matenadaranin Mkhitareants i Venetik. Venice: St. Lazarus. Vol. 4.

28. Ter-Mkrtchean, K. (1990) Pawghikeants ew Tondraketswots aghandnery ardi knnadatuteamb. // Ararat. Mekhitarist Press. N7 (July).

29. Toumayeants, P. (1899) Pontosi hayery. Ashkharhagrakan ew qaghaqakan vitchak Trapizoni. Tpkhis, Lumay, July.

(1974) Zhamanakakits hayots lezvi batsatrakan bararan. Yerevan: NAS, Gitutyun. Vol. 3. 